\title{
Checklist of rodents and insectivores of the Mordovia, Russia
}

\author{
Alexey V. Andreychev', Vyacheslav A. Kuznetsov' \\ I Department of Zoology, National Research Mordovia State University, Bolshevistskaya Street, 68. 430005, \\ Saransk, Russia \\ Corresponding author: Alexey V. Andreychev (teriomordovia@bk.ru)
}

Academiceditor:R.López-Antońanzas | Received7August 2020|Accepted 18November 2020|Published 16December 2020

http://zoobank.org/C127F895-B27D-482E-AD2E-D8E4BDB9F332

Citation: Andreychev AV, Kuznetsov VA (2020) Checklist of rodents and insectivores of the Mordovia, Russia. ZooKeys 1004: 129-139. https://doi.org/10.3897/zookeys.1004.57359

\begin{abstract}
A list of 40 species is presented of the rodents and insectivores collected during a 15-year period from the Republic of Mordovia. The dataset contains more than 24,000 records of rodent and insectivore species from 23 districts, including Saransk. A major part of the data set was obtained during expedition research and at the biological station. The work is based on the materials of our surveys of rodents and insectivorous mammals conducted in Mordovia using both trap lines and pitfall arrays using traditional methods.
\end{abstract}

\section{Keywords}

Insectivores, Mordovia, rodents, spatial distribution

\section{Introduction}

There is a need to review the species composition of rodents and insectivores in all regions of Russia, and the work by Tovpinets et al. (2020) on the Crimean Peninsula serves as an example of such research. Studies of rodent and insectivore diversity and distribution have a long history, but there are no lists for many regions of Russia of 
rodent and insectivorous species. Lists of species have been updated for a few regions, with some species excluded and others added. The Republic of Mordovia is one of these regions, where eminent theriologists (S.I. Ognev, S.S. Turov, L.G. MorozovaTurova, I.I. Barabash-Nikiforov, L.P. Borodin, M.N. Borodina, P.L. Borodin) once worked. The inventory of the mammalian fauna of Mordovia resumed at the beginning of the $21^{\text {st }}$ century as part of dissertation research and continues to this day. Over this period, not only has the species composition of the region changed but also the status of many species.

The Mordovian fauna is heterogeneous and consists of four different ecological and faunal complexes of species-taiga, coniferous and broad-leaved forests, and steppewhich are widely distributed in several natural areas (Andreychev 2020).

Here, we publish a checklist of rodent and insectivore records across the Republic of Mordovia. This checklist was based on comprehensive surveys of small mammals carried out from 2006 to 2020.

Insectivores are represented in Mordovia by 12 species belonging to three families.

\section{Family Erinaceidae Fischer, 1814}

1. Northern white-breasted hedgehog, Erinaceus roumanicus Barrett-Hamilton, 1900

2. West European hedgehog, Erinaceus europaeus Linnaeus, 1758

\section{Family Talpidae Fischer, 1814}

1. European mole, Talpa europaea Linnaeus, 1758

2. Russian desman, Desmana moschata (Linnaeus, 1758)

\section{Family Soricidae Fischer, 1814}

1. Eurasian common shrew, Sorex araneus Linnaeus, 1758

2. Laxmann's shrew, Sorex caecutiens Laxmann, 1788

3. Least shrew, Sorex minutissimus Zimmermann, 1780

4. Taiga shrew, Sorex isodon Turov, 1924

5. Eurasian pygmy shrew, Sorex minutus Linnaeus, 1766

6. Eurasian water shrew, Neomys fodiens (Pennant, 1771)

7. Southern water shrew, Neomys anomalus Cabrera, 1907

8. Lesser white-toothed shrew, Crocidura suaveolens (Pallas, 1811)

Rodents are represented by 29 species belonging to eight families.

\section{Family Sciuridae Fischer, 1817}

1. Red squirrel, Sciurus vulgaris Linnaeus, 1758

2. Spotted suslik, Spermophilus suslicus Güldenstaedt, 1770

3. Bobak marmot, Marmota bobak (Müller, 1776) 


\section{Family Castoridae Hemprich, 1820}

1. Eurasian beaver, Castor fiber Linnaeus, 1758

\section{Family Gliridae Thomas, 1897}

1. Forest dormouse, Dryomys nitedula (Pallas, 1779)

2. Garden dormouse, Eliomys quercinus (Linnaeus, 1766)

3. Fat dormouse, Glis glis (Linnaeus, 1766)

4. Hazel dormouse, Muscardinus avellanarius (Linnaeus, 1758)

\section{Family Sminthidae Brandt, 1855}

1. Northern birch mouse, Sicista betulina (Pallas, 1779)

\section{Family Allactagidae Vinogradov, 1925}

1. Great jerboa, Allactaga major (Kerr, 1792)

\section{Family Spalacidae Gray, 1821}

1. Greater mole rat, Spalax microphthalmus Güldenstaedt, 1770

2. Family Cricetidae Fischer, 1817

3. Bank vole, Myodes glareolus (Schreber, 1780)

4. Northern red-backed vole, Myodes rutilus (Pallas, 1779)

5. European water vole, Arvicola amphibius (Linnaeus, 1758)

6. Root vole, Microtus oeconomus (Pallas, 1776)

7. Gray dwarf hamster, Cricetulus migratorius (Pallas, 1773)

8. Common hamster, Cricetus cricetus (Linnaeus, 1758)

9. Muskrat, Ondatra zibethicus (Linnaeus, 1766)

10. Steppe lemming, Lagurus lagurus Pallas, 1773

11. Common vole, Microtus arvalis (Pallas, 1779)

12. East European vole, Microtus rossiaemeridionalis Ognev, 1924

13. Field vole, Microtus agrestis (Linnaeus, 1761)

14. European pine vole, Microtus subterraneus (de Selys-Longchamps, 1836)

\section{Family Muridae Illiger, 1811}

1. Striped field mouse, Apodemus agrarius (Pallas, 1771)

2. Pygmy wood mouse, Apodemus uralensis (Pallas, 1811)

3. Yellow-necked wood mouse, Apodemus flavicollis (Melchior, 1834)

4. Harvest mouse, Micromys minutus (Pallas, 1771)

5. House mouse, Mus musculus Linnaeus, 1758

6. Norway rat, Rattus norvegicus (Berkenhout, 1769) 
Genetic studies of two similar species, Microtus arvalis and M. rossiaemeridionalis, have not been conducted in the region. Approaches and criteria for differentiation of two similar species, Erinaceus roumanicus and E. europaeus, have been applied for a number of specific morphological and craniometric characteristics (Zaitsev 1984; Frost et al. 1991). First, E. roumanicus has a patch of white hair on its belly. And E. europaeus has no white hair on its belly. Differences in the skull are also apparent; in E. roumanicus, the premaxillary-maxillary suture has one or two inflections (in E. europaeus it is smooth), the length of the premaxillary-nasal suture does not exceed $9.0 \mathrm{~mm}$ (in E. europaeus $>9.0 \mathrm{~mm}$ ), and the maximum length of the nasal bones in their back part is greater than or equal to $3.0 \mathrm{~mm}$ (E. europaeus $<3.0 \mathrm{~mm}$ ) (Zaitsev 1984; Frost et al. 1991; Zaitsev et al. 2014). The color of the needles of these two species can serve as a criteria for their differences. Six species (Eliomys quercinus, Cricetulus migratorius, Lagurus lagurus, Myodes rutilus, Microtus subterraneus, and Neomys anomalus) reported from the Republic of Mordovia were not detected during our surveys. However, these species were captured by our colleagues, either long ago or even in the last year, and most of them (E. quercinus, C. migratorius, L. lagurus, and M. rutilus) were recorded in the Mordovian state nature reserve, Temnikovsky district (Borodina et al. 1970). Microtus subterraneus has recently been found in Mordovia (Kirillova et al. 2019). This record represents the easternmost occurrence of of this species. Previously, this underground vole was recorded in neighboring regions of Mordovia, namely near the village of Zhelannoe in Ryazan region and from Zametchinsky district in Penza region. This species is rare and included in Red Data Books of several Russian regions, including the Leningrad, Tver, Penza, Moscow, Pskov reion, and Novgorod regions. The appearance of a new species for Mordovia can be explained by its expansion into new territories. This is confirmed by the new record of this species from the Smolensk region (Belyaev 2020). In addition, a species atypical of the Mordovian fauna, Neomys anomalus, is now known (Borodin 2013).

From an ecological perspective, mesophilous species comprise the largest group, which includes 26 species. Some xerophilous species (M. bobak, Sp. suslicus, Al. major, Sp. microphthalmus, Cr. migratorius, Cr. cricetus, L. lagurus, and M. minutus) occur only in steppe habitats. Only in the steppe areas of Mordovia are there concentrated populations of S. microphthalmus (Andreychev 2018, 2019) and M. bobak (Andreychev et al. 2015). Populations of S. microphthalmus in Mordavia are vulnerable, as in other parts of its range (Zagorodniuk et al. 2018). Grazing is important here for M. bobak, as has been shown for Ukraine (Rashevska and Semeniuk 2015; Tokarsky 2015; Savchenko and Ronkin 2018).

Dendrophile rodents are represented by only seven species: D. nitedula, G. glis, $M$. avellanarius, E. quercinus, $S$. vulgaris, A. flavicollis, and $A$. uralensis. Of these species, the most studied in the region are D. nitedula (Andreychev and Boyarova 2020; Andreychev and Kiyaykina 2020), A. flavicollis, and A. uralensis (Andreychev and Kuznetsov 2012).

Thirteen species are associated with human settlements, C. suaveolens, E. roumanicus, S. minutus, S. araneus, S. isodon, C. cricetus, M. glareolus, M. arvalis, A. agrarius, A. uralensis, A. flavicollis, M. musculus, and $R$. norvegicus, and these have been repeatedly been recorded in residential areas. However, only three species, M. musculus, $R$. norvegicus, and $C$. suaveolens, are truly commensal. 
The rodent and insectivore fauna of Mordovia is in general large, as it includes both steppe and taiga species. The largest rodent of Mordovia is $C$. fiber, which is widely distributed in the region's water bodies (Andreychev 2017). The rodent and insectivore fauna of Mordovia is larger than in adjacent regions. However, the fauna lacks some species that exist in adjacent regions: Ulyanovsk region - Allocricetulus eversmanni Brandt, 1859 (Red Book 2008); Penza region - Spermophilus major Pallas, 1778, Sicista strandi (Formozov, 1931) (Il'in et al. 2006); Nizhny Novgorod region - Rattus rattus (Linnaeus, 1758), Tamias sibiricus (Laxmann, 1769), Pteromys volans (Linnaeus, 1758), Myodes rufocanus (Sundevall, 1846) (Krivonogov et al. 2008); Chuvash region Tamias sibiricus (Laxmann, 1769), Pteromys volans (Linnaeus, 1758) (Red Book 2010); and Ryazan region - Rattus rattus (Linnaeus, 1758), Pteromys volans (Linnaeus, 1758) (Red Book 2011). Thus, seven species of rodents and insectivores present in adjacent regions are absent from the fauna of Mordovia.

\section{Taxonomic coverage}

The dataset contains more than 24,000 registrations of rodent and insectivore species from the districts of the Republic of Mordovia, including Saransk (Table 1, Appendix 1).

\section{Taxonomic ranks}

Kingdom: Animalia

Phylum: Chordata

Class: Mammalia

Order: Eulipotyphla, Rodentia

Family: Erinaceidae, Talpidae, Soricidae, Sciuridae, Castoridae, Gliridae, Sminthidae, Allactagidae, Spalacidae, Cricetidae, Muridae

Genus: Talpa, Desmana, Sorex, Neomys, Crocidura, Sciurus, Spermophilus, Marmota, Castor, Dryomys, Eliomys, Glis, Muscardinus, Sicista, Allactaga, Spalax, Myodes, Arvicola, Microtus, Cricetulus, Cricetus, Ondatra, Lagurus, Microtus, Apodemus, Micromys, Mus, Rattus

Species: Erinaceus roumanicus, Erinaceus europaeus, Talpa europaea, Desmana moschata, Sorex araneus, Sorex caecutiens, Sorex minutissimus, Sorex isodon, Sorex minutus, Neomys fodiens, Neomys anomalus, Crocidura suaveolens, Sciurus vulgaris, Spermophilus suslicus, Marmota bobak, Castor fiber, Dryomys nitedula, Eliomys quercinus, Glis glis, Muscardinus avellanarius, Sicista betulina, Allactaga major, Spalax microphthalmus, Myodes glareolus, Myodes rutilus, Arvicola amphibius, Microtus oeconomus, Cricetulus migratorius, Cricetus cricetus, Ondatra zibethicus, Lagurus lagurus, Microtus arvalis, Microtus rossiaemeridionalis, Microtus agrestis, Microtus subterraneus, Apodemus agrarius, Apodemus uralensis, Apodemus flavicollis, Micromys minutus, Mus musculus, Rattus norvegicus 
Table I. Registration points of rodents and insectivores collected in the Mordovia.

\begin{tabular}{|c|c|c|}
\hline Species no. & Species & Points no. (from Appendix 1) \\
\hline 1 & Erinaceus roumanicus & $17,25,31,32,46,63,75,99,102$ \\
\hline 2 & Erinaceus europaeus & 34,103 \\
\hline 3 & Talpa europaea & $1,8,11,17,24,33,36,40,44,53,56,63,64,67,73,76,81,85,97,98,102,103,105$ \\
\hline 4 & Desmana moschata & $68,73,76,81,95,97,101$ \\
\hline 5 & Sorex araneus & $6,8,11,22,24,28,33,35,40,45,51,53,56,63,64,67,73,77,83,89,98,102,103$ \\
\hline 6 & Sorex caecutiens & $37,71,67,76,93,97,102,103$ \\
\hline 7 & Sorex minutissimus & 76 \\
\hline 8 & Sorex isodon & $14,37,52,59,62,66,74,94,96,102,103$ \\
\hline 9 & Sorex minutus & $10,11,22,24,26,33,35,40,45,51,53,56,58,63,65,67,73,77,82,91,98,102,103$ \\
\hline 10 & Neomys fodiens & $12,17,33,40,47,49,53,55,63,69,73,76,80,84,86,97,101,102,103,105$ \\
\hline 11 & Neomys anomalus & 76 \\
\hline 12 & Crocidura suaveolens & $20,36,76,102$ \\
\hline 13 & Sciurus vulgaris & $17,31,34,38,44,56,63,67,73,76,88,97,100,102$ \\
\hline 14 & Spermophilus suslicus & $7,31,23,33$ \\
\hline 15 & Marmota bobak & $1,21,31,32,39,62$ \\
\hline 16 & Castor fiber & $1,8,11,17,24,33,36,40,44,53,56,63,64,67,73,76,81,85,97,98,102,103,105$ \\
\hline 17 & Dryomys nitedula & $36,76,102,103$ \\
\hline 18 & Eliomys quercinus & 17,76 \\
\hline 19 & Glis glis & $4,38,42,76,102$ \\
\hline 20 & Muscardinus avellanarius & $17,56,102,103$ \\
\hline 21 & Sicista betulina & $76,100,102,103$ \\
\hline 22 & Allactaga major & $31,33,69,85$ \\
\hline 23 & Spalax microphthalmus & 11,19 \\
\hline 24 & Myodes glareolus & $1,8,11,17,24,33,36,40,44,53,56,63,64,67,73,76,81,85,97,98,102,103,105$ \\
\hline 25 & Myodes rutilus & 76 \\
\hline 26 & Arvicola amphibius & $1,8,11,17,24,33,36,40,44,53,56,63,64,67,73,76,81,85,97,98,102,103,105$ \\
\hline 27 & Microtus oeconomus & $24,61,70,76,92,102,103$ \\
\hline 28 & Cricetulus migratorius & 76 \\
\hline 29 & Cricetus cricetus & $3,5,9,16,18,24,33,37,50,62,98,104$ \\
\hline 30 & Ondatra zibethicus & $1,8,11,17,24,33,36,40,44,53,56,63,64,67,73,76,81,85,97,98,102,103,105$ \\
\hline 31 & Lagurus lagurus & 31,76 \\
\hline 32 & Microtus arvalis s.l. & $1,8,11,17,24,33,36,40,44,53,56,63,64,67,73,76,81,85,97,98,102,103,105$ \\
\hline 33 & Microtus agrestis & $72,76,87,102,103$ \\
\hline 34 & Microtus subterraneus & 102 \\
\hline 35 & Apodemus agrarius & $10,11,22,24,27,33,35,40,45,51,53,56,58,63,65,67,73,77,82,91,98,102,103$ \\
\hline 36 & Apodemus uralensis & $1,8,11,17,24,33,36,40,44,53,56,63,64,67,73,76,81,85,97,98,102,103,105$ \\
\hline 37 & Apodemus flavicollis & $2,29,30,33,41,54,56,57,60,63,73,78,79,90,97,103$ \\
\hline 38 & Micromys minutus & $13,17,31,43,48,71,76,102$ \\
\hline 39 & Mus musculus & $10,11,22,24,27,33,35,40,45,51,53,56,58,63,65,67,73,77,82,91,98,102,103$ \\
\hline 40 & Rattus norvegicus & $1,8,11,17,24,33,36,40,44,53,56,63,64,67,73,76,81,85,97,98,102,103,105$ \\
\hline
\end{tabular}

\section{Spatial coverage}

The dataset covers the entire Republic of Mordovia within $53^{\circ} 38^{\prime} \mathrm{N}$ to $55^{\circ} 11^{\prime} \mathrm{N}$ and $42^{\circ} 11^{\prime} \mathrm{E}$ to $46^{\circ} 45^{\prime} \mathrm{E}$.

\section{Temporal coverage}

The data were collected from 2006 to 2020 . 


\section{Method}

Most of the dataset was obtained in the Republic of Mordovia during expedition research and at the biological station. The work is based on the materials of our surveys of rodents and insectivorous mammals conducted in the Republic of Mordovia, using trap lines and pitfall arrays using traditional methods. Small rodents were captured using small spring snap-traps $(120 \times 55 \mathrm{~mm})$ left over night in lines of from 50 to 100 traps with a distance of $5 \mathrm{~m}$ between them and baited with bread and sunflower oil. We also used live traps baited with salami and apple to catch dormice. Voucher specimens are stored in the personal collection A. Andreychev, Saransk (teriomordovia@bk.ru). Data on Erinaceus roumanicus, Erinaceus europaeus, Talpa europaea, Desmana moschata, Sciurus vulgaris, Spermophilus suslicus, Marmota bobak, Castor fiber, Allactaga major, Spalax microphthalmus, Cricetus cricetus, and Ondatra zibethicus were obtained via direct observations, recording and/or detection of the traces of their activities (tracks, burrows, etc.). Latin names of species are given according to the classical nomenclature (Wilson and Reeder 2005).

\section{Acknowledgements}

We thank A. Zhalilov and G. Salmov for their valuable comments on and corrections to the manuscript.

\section{References}

Andreychev A (2017) Population density of the Eurasian beaver (Castor fiber L.) (Castoridae, Rodentia) in the Middle Volga of Russia. Forestry Studies 67(1): 109-115. https://doi. org/10.1515/fsmu-2017-0016

Andreychev AV (2018) A new methodology for studying the activity of underground mammals. Biology Bulletin 45(8): 937-943. https://doi.org/10.1134/S1062359018080022

Andreychev AV (2019) Daily and seasonal feeding activity of the greater mole-rat (Spalax microphthalmus, Rodentia, Spalacidae). Biology Bulletin 46(9): 1172-1181. https://doi. org/10.1134/S1062359019090012

Andreychev A (2020) Ecological and faunal complexes of insectivorous mammals of the Republic of Mordovia, Russia. Biodiversitas 21: 3344-3349. https://doi.org/10.13057/bio$\operatorname{div} / \mathrm{d} 210758$

Andreychev A, Boyarova E (2020) Forest dormouse (Dryomys nitedula, Rodentia, Gliridae) - a highly contagious rodent in relation to zoonotic diseases. Forestry Ideas 26(1): 262-269.

Andreychev AV, Kiyaykina OS (2020) Homing in the forest dormouse (Dryomys nitedula, Rodentia, Gliridae). Zoologicheskii Zhurnal 99(6): 698-705. https://doi.org/10.31857/ S0044513420060033

Andreychev AV, Kuznetsov VA (2012) Mammals of Mordovia. Mordovia State University, Saransk, 100 pp. 
Andreychev AV, Zhalilov AB, Kuznetsov VA (2015) The state of local steepe woodchuck (Marmota bobak) populations in the Republic of Mordovia. Zoologicheskii Zhurnal 94(6): 723-730. https://doi.org/10.7868/S0044513415060033

Belyaev DA (2020) The European pine vole, Microtus subterraneus Selys-longchamps 1836

(Rodentia, Cricetidae), a mammal species new to the fauna of the Smolensk region. Zoologicheskii Zhurnal 99(2): 234-238. https://doi.org/10.31857/S0044513420020051

Borodin PL (2013) Mediterranean water shrew in the Mordovian nature reserve. Proceedings of the Mordovian State Nature Reserve 11: 109-124.

Borodina MN, Borodin LP, Tereshkin IS, Shtarev YuF (1970) Mammals of the Mordovia Reserve. Proceedings of the Mordovian State Nature Reserve 5: 5-60.

Frost DR, Wozencraft WC, Hoffmann RS (1991) Phylogenetic relationships of hedgehogs and gymnures (Mammalia: Insectivora: Erinaceidae). Smithsonian Contributions to Zoology 518: 62-63. https://doi.org/10.5479/si.00810282.518

Il'in VY, Bystrakova NV, Dobrolyubov AN, Ermakov OA, Zolina NF, Kurmayeva NM, Lukyanov SB, Pavlova SV, Smirnov DG, Titov SV (2006) Synapsis of mammalian fauna of the Penza oblast. Izvestiya Penzenskogo Gosudarstvennogo Pedagogicheskogo Universiteta imeni V.G. Belinskogo 1(5): 73-89.

Kirillova NYu, Krystufek B, Kirillov AA, Ruchin AB, Grishutkin GF (2019) The first record of Microtus subterraneus (de Sélys-Longchamps, 1836) (Rodentia, Cricetidae) for Mordovia, Russia. Acta Biologica Sibirica 5(4): 145-149. https://doi.org/10.14258/abs.v5.i4.7149

Krivonogov DM, Dmitriev AI, Zamoreva ZA, Trushkova MA, Sokolova ES, Yurochkina OG, Simagin AS, Abramova ON (2008) Mammals of the Red Book of the Nizhny Novgorod region (current state and environmental status). Rare Species of Living Organisms of the Nizhny Novgorod Region. N. Novgorod, 1: 116-123.

Red Book of the Chuvash region (2010) Red Book of the Chuvash region. Publishing house of Chuvashia, Cheboksary, 372 pp.

Red Data Book of Ryazan Region (2011) Red Data Book of Ryazan Region. Golos gubernii Publ., Ryazan, 626 pp. [In Russian]

Red Book of the Ulyanovsk region (2008) Red Book of the Ulyanovsk region. Artishok, Ulyanovsk, 508 pp.

Savchenko G, Ronkin V (2018) Grazing, abandonment and frequent mowing influence the persistence of the steppe marmot, Marmota bobak. Hacquetia 17(1): 25-34. https://doi. org/10.1515/hacq-2017-0009

Rashevska HV, Semeniuk SK (2015) A unique colony of the bobak marmot, Marmota bobak (Rodentia, Sciuridae), in steppes of the right-bank Ukraine. Vestnik Zoologii 49(4): 377-378. https://doi.org/10.1515/vzoo-2015-0042

Tokarsky V (2015) A pasture of big ungulate animals as key ecological factor influencing on the fluctuation of natural habitat of steppe herbivorous mammals. Vestnik Zoologii 49(2): 159-170. https://doi.org/10.1515/vzoo-2015-0018

Tovpinets NN, Evstafiev IL, Stakheev VV, Lissovsky AA (2020) Checklist of rodents and insectivores of the Crimean Peninsula. ZooKeys 948: 121-127. https://doi.org/10.3897/zookeys.948.51275

Zagorodniuk I, Korobchenko M, Parkhomenko V, Barkaszi Z (2018) Steppe rodents at the edge of their range: a case study of Spalax microphthalmus in the north of Ukraine. Biosystems Diversity 26(3): 188-200. https://doi.org/10.15421/011829 
Zaitsev MV (1984) Systematics and diagnostics of hedgehogs of the subgenus Erinaceus (Mammalia, Erinaceinae) of the fauna of the USSR. Zoologicheskii Zhurnal 63(5): 720-730.

Zaitsev MV, Voyta LL, Sheftel BI (2014) The mammals of Russia and adjacent territories. Lipotyphlans. Zoological Institute Russian Academy of Sciences, Saint Petersburg, 391 pp. Wilson DE, Reeder DM (2005) Mammal Species of the World, Third Edition. Vol. 1. The Johns Hopkins University Press, Baltimore, 743 pp.

\section{Appendix I}

Points of the Republic of Mordovia in which mammals are recorded.

\begin{tabular}{|c|c|c|c|}
\hline Points no. & District & Location & Geographic coordinates \\
\hline 1 & Lyambirskiy & Atemar & $54.0980^{\circ} \mathrm{N}, 45.2138^{\circ} \mathrm{E}$ \\
\hline 2 & Kochkurovskiy & Vorob'evka & $54.0251^{\circ} \mathrm{N}, 45.1754^{\circ} \mathrm{E}$ \\
\hline 3 & & Vnukovka & $54.0118^{\circ} \mathrm{N}, 45.1609^{\circ} \mathrm{E}$ \\
\hline 4 & & Novotyaglovka & $53.5506^{\circ} \mathrm{N}, 45.1778^{\circ} \mathrm{E}$ \\
\hline 5 & Ichalkovskiy & Lobaski & $54.3662^{\circ} \mathrm{N}, 45.1007^{\circ} \mathrm{E}$ \\
\hline 6 & Lyambirskiy & Cheremishevo & $54.1579^{\circ} \mathrm{N}, 45.0604^{\circ} \mathrm{E}$ \\
\hline 7 & Romodanovskiy & Malaya Chfarovka & $54.2435^{\circ} \mathrm{N}, 45.1750^{\circ} \mathrm{E}$ \\
\hline 8 & & Romodanovo & $54.2494^{\circ} \mathrm{N}, 45.2043^{\circ} \mathrm{E}$ \\
\hline 9 & & Kavtorovka & $54.2187^{\circ} \mathrm{N}, 45.1491^{\circ} \mathrm{E}$ \\
\hline 10 & & Kurilovo & $54.2854^{\circ} \mathrm{N}, 45.2805^{\circ} \mathrm{E}$ \\
\hline 11 & Ruzaevskiy & Levzhenskij & $54.0618^{\circ} \mathrm{N}, 45.0517^{\circ} \mathrm{E}$ \\
\hline 12 & & Popovka & $54.0690^{\circ} \mathrm{N}, 45.0310^{\circ} \mathrm{E}$ \\
\hline 13 & & Klyucharevo & $54.0846^{\circ} \mathrm{N}, 45.0121^{\circ} \mathrm{E}$ \\
\hline 14 & & Ruzaevka & $54.0246^{\circ} \mathrm{N}, 44.5609^{\circ} \mathrm{E}$ \\
\hline 15 & & Bogolyubovka & $54.0596^{\circ} \mathrm{N}, 44.5238^{\circ} \mathrm{E}$ \\
\hline 16 & & Tatarskij Shebdas & $53.5851^{\circ} \mathrm{N}, 44.5444^{\circ} \mathrm{E}$ \\
\hline 17 & Saransk & Saransk & $54.1328^{\circ} \mathrm{N}, 45.1102^{\circ} \mathrm{E}$ \\
\hline 18 & & Zykovo & $54.0495^{\circ} \mathrm{N}, 45.0589^{\circ} \mathrm{E}$ \\
\hline 19 & & Dobrovol'nyj & $54.0807^{\circ} \mathrm{N}, 45.0506^{\circ} \mathrm{E}$ \\
\hline 20 & & Pushkino & $54.0815^{\circ} \mathrm{N}, 45.1151^{\circ} \mathrm{E}$ \\
\hline 21 & & Makarovka & $54.1037^{\circ} \mathrm{N}, 45.1717^{\circ} \mathrm{E}$ \\
\hline 22 & & Kulikovka & $54.0689^{\circ} \mathrm{N}, 45.1217^{\circ} \mathrm{E}$ \\
\hline 23 & Ardatovskiy & Zharenki & $54.4420^{\circ} \mathrm{N}, 46.1421^{\circ} \mathrm{E}$ \\
\hline 24 & Atyashevskiy & Tarasovo & $54.3578^{\circ} \mathrm{N}, 46.1334^{\circ} \mathrm{E}$ \\
\hline 25 & Chamzinskiy & Rep'evka & $54.2468^{\circ} \mathrm{N}, 45.4177^{\circ} \mathrm{E}$ \\
\hline 26 & & Gorbunovka & $54.3030^{\circ} \mathrm{N}, 45.5188^{\circ} \mathrm{E}$ \\
\hline 27 & & Azar'evka & $54.3367^{\circ} \mathrm{N}, 45.3987^{\circ} \mathrm{E}$ \\
\hline 28 & & Komsomol'skij & $54.2672^{\circ} \mathrm{N}, 45.5183^{\circ} \mathrm{E}$ \\
\hline 29 & & Lyulya & $54.2755^{\circ} \mathrm{N}, 45.5589^{\circ} \mathrm{E}$ \\
\hline 30 & Ichalkovskiy & Vechkusy & $54.4196^{\circ} \mathrm{N}, 45.3641^{\circ} \mathrm{E}$ \\
\hline 31 & Bol'shebereznikovskiy & Simkino & $54.1527^{\circ} \mathrm{N}, 46.1168^{\circ} \mathrm{E}$ \\
\hline 32 & Dubenskiy & Engalychevo & $54.1846^{\circ} \mathrm{N}, 46.2649^{\circ} \mathrm{E}$ \\
\hline 33 & & Nikolaevka & $54.2105^{\circ} \mathrm{N}, 46.3065^{\circ} \mathrm{E}$ \\
\hline 34 & & Purkaevo & $54.2316^{\circ} \mathrm{N}, 46.3625^{\circ} \mathrm{E}$ \\
\hline 35 & Kochkurovskiy & Novaya Pyrma & $54.0017^{\circ} \mathrm{N}, 45.2922^{\circ} \mathrm{E}$ \\
\hline 36 & Chamzinskiy & Chamzinka & $54.2318^{\circ} \mathrm{N}, 45.4739^{\circ} \mathrm{E}$ \\
\hline 37 & & Medaevo & $54.2593^{\circ} \mathrm{N}, 46.0009^{\circ} \mathrm{E}$ \\
\hline 38 & & Pyangelej & $54.1778^{\circ} \mathrm{N}, 45.4172^{\circ} \mathrm{E}$ \\
\hline 39 & & Picheury & $54.1847^{\circ} \mathrm{N}, 45.4883^{\circ} \mathrm{E}$ \\
\hline 40 & Insarskiy & Luhmenskij Majdan & $53.4460^{\circ} \mathrm{N}, 44.1146^{\circ} \mathrm{E}$ \\
\hline 41 & & Potulovka & $53.4215^{\circ} \mathrm{N}, 44.2515^{\circ} \mathrm{E}$ \\
\hline
\end{tabular}




\begin{tabular}{|c|c|c|c|}
\hline Points no. & District & Location & Geographic coordinates \\
\hline 42 & Kadoshkinskiy & Adashevo & $53.5712^{\circ} \mathrm{N}, 44.1884^{\circ} \mathrm{E}$ \\
\hline 43 & Kovylkinskiy & Mordovskoe Kolomasovo & $53.5837^{\circ} \mathrm{N}, 44.0684^{\circ} \mathrm{E}$ \\
\hline 44 & Atyur'evskiy & Shustruj & $54.1441^{\circ} \mathrm{N}, 43.2251^{\circ} \mathrm{E}$ \\
\hline 45 & & Kurtashki & $54.1916^{\circ} \mathrm{N}, 43.2639^{\circ} \mathrm{E}$ \\
\hline 46 & Zubovo-Polyanskiy & Achadovo & $53.5385^{\circ} \mathrm{N}, 43.0009^{\circ} \mathrm{E}$ \\
\hline 47 & Kovylkinskiy & Gumny & $54.0067^{\circ} \mathrm{N}, 43.4337^{\circ} \mathrm{E}$ \\
\hline 48 & Krasnoslobodskiy & Zheltonogovo & $54.2875^{\circ} \mathrm{N}, 43.4456^{\circ} \mathrm{E}$ \\
\hline 49 & & Slobodskie Dubrovki & $54.2483^{\circ} \mathrm{N}, 43.3468^{\circ} \mathrm{E}$ \\
\hline 50 & Temnikovskiy & Bulaevo & $54.3331^{\circ} \mathrm{N}, 43.3354^{\circ} \mathrm{E}$ \\
\hline 51 & Torbeevskiy & Salazgor' & $54.0718^{\circ} \mathrm{N}, 43.0735^{\circ} \mathrm{E}$ \\
\hline 52 & & Drakino & $54.0269^{\circ} \mathrm{N}, 43.1445^{\circ} \mathrm{E}$ \\
\hline 53 & Kadoshkinskiy & Pushkino & $54.0528^{\circ} \mathrm{N}, 44.2329^{\circ} \mathrm{E}$ \\
\hline 54 & Ruzaevskiy & Boldovo & $53.5981^{\circ} \mathrm{N}, 44.3908^{\circ} \mathrm{E}$ \\
\hline 55 & Staroshajgovskiy & Mal'keevka & $54.2428^{\circ} \mathrm{N}, 44.4723^{\circ} \mathrm{E}$ \\
\hline 56 & & Staraya Terizmorga & $54.1569^{\circ} \mathrm{N}, 44.3043^{\circ} \mathrm{E}$ \\
\hline 57 & Lyambirskiy & Dal'nij & $54.2883^{\circ} \mathrm{N}, 44.5892^{\circ} \mathrm{E}$ \\
\hline 58 & & Yazykovo & $54.2680^{\circ} \mathrm{N}, 44.5864^{\circ} \mathrm{E}$ \\
\hline 59 & & Lopatino & $54.1738^{\circ} \mathrm{N}, 45.0136^{\circ} \mathrm{E}$ \\
\hline 60 & Ardatovskiy & Kurakino & $54.5645^{\circ} \mathrm{N}, 46.0831^{\circ} \mathrm{E}$ \\
\hline 61 & & Staroe Ardatovo & $54.5843^{\circ} \mathrm{N}, 46.1336^{\circ} \mathrm{E}$ \\
\hline 62 & Bol'sheignatovskiy & Petrovka & $54.5854^{\circ} \mathrm{N}, 45.2930^{\circ} \mathrm{E}$ \\
\hline 63 & & Kirzhemany & $54.5850^{\circ} \mathrm{N}, 45.4432^{\circ} \mathrm{E}$ \\
\hline 64 & Kovylkinskiy & Rybkino & $54.1531^{\circ} \mathrm{N}, 43.4799^{\circ} \mathrm{E}$ \\
\hline 65 & & Kovylyaj & $54.1016^{\circ} \mathrm{N}, 43.5071^{\circ} \mathrm{E}$ \\
\hline 66 & Krasnoslobodskiy & Krasnaya Podgora & $54.2887^{\circ} \mathrm{N}, 43.4870^{\circ} \mathrm{E}$ \\
\hline 67 & & Lesnoj & $54.2613^{\circ} \mathrm{N}, 43.5214^{\circ} \mathrm{E}$ \\
\hline 68 & & Zarechnoe & $54.2469^{\circ} \mathrm{N}, 43.5124^{\circ} \mathrm{E}$ \\
\hline 69 & & Staraya Ryabka & $54.2050^{\circ} \mathrm{N}, 43.5046^{\circ} \mathrm{E}$ \\
\hline 70 & & Samozlejka & $54.1829^{\circ} \mathrm{N}, 43.4931^{\circ} \mathrm{E}$ \\
\hline 71 & El'nikovskiy & Churino & $54.3995^{\circ} \mathrm{N}, 43.4471^{\circ} \mathrm{E}$ \\
\hline 72 & & Russkie Poshaty & $54.4078^{\circ} \mathrm{N}, 43.4436^{\circ} \mathrm{E}$ \\
\hline 73 & & Starye Pichingushi & $54.3391^{\circ} \mathrm{N}, 43.5029^{\circ} \mathrm{E}$ \\
\hline 74 & Temnikovskiy & Staryj Gorod & $54.4175^{\circ} \mathrm{N}, 43.0609^{\circ} \mathrm{E}$ \\
\hline 75 & & Temnikov & $54.3748^{\circ} \mathrm{N}, 43.1139^{\circ} \mathrm{E}$ \\
\hline 76 & & MGZ im. P.G. Smidovicha & $54.4286^{\circ} \mathrm{N}, 43.1423^{\circ} \mathrm{E}$ \\
\hline 77 & & Kozlovka & $54.3816^{\circ} \mathrm{N}, 43.2114^{\circ} \mathrm{E}$ \\
\hline 78 & & Sosnovka & $54.4281^{\circ} \mathrm{N}, 43.1683^{\circ} \mathrm{E}$ \\
\hline 79 & Ten'gushevskiy & Standrovo & $54.3953^{\circ} \mathrm{N}, 42.3943^{\circ} \mathrm{E}$ \\
\hline 80 & & Shelubej & $54.4074^{\circ} \mathrm{N}, 42.4291^{\circ} \mathrm{E}$ \\
\hline 81 & & Telimerki & $54.4364^{\circ} \mathrm{N}, 42.4580^{\circ} \mathrm{E}$ \\
\hline 82 & & Feklisov & $54.4289^{\circ} \mathrm{N}, 42.5073^{\circ} \mathrm{E}$ \\
\hline 83 & & Vedenyapino & $54.4416^{\circ} \mathrm{N}, 42.5857^{\circ} \mathrm{E}$ \\
\hline 84 & Atyur'evskiy & Arga & $54.2034^{\circ} \mathrm{N}, 43.0912^{\circ} \mathrm{E}$ \\
\hline 85 & Zubovo-Polyanskiy & Podlyasovo & $54.1941^{\circ} \mathrm{N}, 42.4184^{\circ} \mathrm{E}$ \\
\hline 86 & & Svezhen'kaya & $54.0035^{\circ} \mathrm{N}, 42.2674^{\circ} \mathrm{E}$ \\
\hline 87 & & Izvest' & $53.5609^{\circ} \mathrm{N}, 42.2746^{\circ} \mathrm{E}$ \\
\hline 88 & & Vysha & $53.5033^{\circ} \mathrm{N}, 42.2320^{\circ} \mathrm{E}$ \\
\hline 89 & & Gorodishche & $53.4553^{\circ} \mathrm{N}, 42.2921^{\circ} \mathrm{E}$ \\
\hline 90 & & Zhukovka & $53.5293^{\circ} \mathrm{N}, 42.4358^{\circ} \mathrm{E}$ \\
\hline 91 & & Shiringushi & $53.5123^{\circ} \mathrm{N}, 42.4571^{\circ} \mathrm{E}$ \\
\hline 92 & & Ozernyj & $54.2510^{\circ} \mathrm{N}, 42.4141^{\circ} \mathrm{E}$ \\
\hline 93 & & Lesnoj & $54.2774^{\circ} \mathrm{N}, 42.4323^{\circ} \mathrm{E}$ \\
\hline 94 & & Romanovka & $54.1481^{\circ} \mathrm{N}, 42.4416^{\circ} \mathrm{E}$ \\
\hline
\end{tabular}




\begin{tabular}{lccc}
\hline \multicolumn{1}{c}{ Points no. } & District & Location & Geographic coordinates \\
\hline 95 & Zubovo-Polyanskiy & Leplej & $54.1883^{\circ} \mathrm{N}, 42.4890^{\circ} \mathrm{E}$ \\
96 & Ten'gushevskiy & Yuzga & $54.3277^{\circ} \mathrm{N}, 42.5919^{\circ} \mathrm{E}$ \\
97 & Torbeevskiy & Vindrej & $54.1554^{\circ} \mathrm{N}, 42.5523^{\circ} \mathrm{E}$ \\
98 & Ardatovskiy & Turgenevo & $54.5150^{\circ} \mathrm{N}, 46.1648^{\circ} \mathrm{E}$ \\
99 & & Redkodub'e & $54.4743^{\circ} \mathrm{N}, 46.0990^{\circ} \mathrm{E}$ \\
100 & & Lun'ga & $54.4864^{\circ} \mathrm{N}, 45.5652^{\circ} \mathrm{E}$ \\
101 & & Lun'ginskij Majdan & $54.5046^{\circ} \mathrm{N}, 45.4821^{\circ} \mathrm{E}$ \\
102 & Ichalkovskiy & Smol'nyj & $54.4592^{\circ} \mathrm{N}, 45.3690^{\circ} \mathrm{E}$ \\
103 & Bol'shebereznikovskiy & Biologicheskaya stanciya MGU & $54.1014^{\circ} \mathrm{N}, 46.0988^{\circ} \mathrm{E}$ \\
104 & & Special'nyj & $54.0262^{\circ} \mathrm{N}, 45.5324^{\circ} \mathrm{E}$ \\
105 & Kochkurovskiy & Mordovskoe Davydovo & $53.5856^{\circ} \mathrm{N}, 45.4535^{\circ} \mathrm{E}$ \\
\hline
\end{tabular}

